\title{
FIGURAÇÕES DA RELIGIÃO CRISTÃ EM JOSÉ DE ALENCAR: ENTRE SANTOS, ERRANTES E AMALDIÇOADOS
}

\author{
Rafaela Mendes Mano Sanches
}

Submetido em 25 de abril de 2019.

Aceito para publicação em 04 de setembro de 2019.

Cadernos do IL, Porto Alegre, n. ${ }^{\circ}$ 58, outubro. p. 134-149.

\section{POLÍTICA DE DIREITO AUTORAL}

Autores que publicam nesta revista concordam com os seguintes termos:

(a) Os autores mantêm os direitos autorais e concedem à revista o direito de primeira publicação, com o trabalho simultaneamente licenciado sob a Creative Commons Attribution License, permitindo o compartilhamento do trabalho com reconhecimento da autoria do trabalho e publicação inicial nesta revista.

(b) Os autores têm autorização para assumir contratos adicionais separadamente, para distribuição não exclusiva da versão do trabalho publicada nesta revista (ex.: publicar em repositório institucional ou como capítulo de livro), com reconhecimento de autoria e publicação inicial nesta revista.

(c) Os autores têm permissão e são estimulados a publicar e distribuir seu trabalho online (ex.: em repositórios institucionais ou na sua página pessoal) a qualquer ponto antes ou durante o processo editorial, já que isso pode gerar alterações produtivas, bem como aumentar o impacto e a citação do trabalho publicado.

(d) Os autores estão conscientes de que a revista não se responsabiliza pela solicitação ou pelo pagamento de direitos autorais referentes às imagens incorporadas ao artigo. A obtenção de autorização para a publicação de imagens, de autoria do próprio autor do artigo ou de terceiros, é de responsabilidade do autor. Por esta razão, para todos os artigos que contenham imagens, o autor deve ter uma autorização do uso da imagem, sem qualquer ônus financeiro para os Cadernos do IL.

\section{POLÍTICA DE ACESSO LIVRE}

Esta revista oferece acesso livre imediato ao seu conteúdo, seguindo o princípio de que disponibilizar gratuitamente o conhecimento científico ao público proporciona sua democratização. 


\title{
FIGURAÇÕES DA RELIGIÃO CRISTÃ EM JOSÉ DE ALENCAR: ENTRE SANTOS, ERRANTES E AMALDIÇOADOS
}

\section{FIGURATIONS OF THE CHRISTIAN RELIGION IN THE FICTIONAL NARRATIVES BY JOSÉ DE ALENCAR: AMIDST SAINTS, ERRATS AND CURSED}

\author{
Rafaela Mendes Mano Sanches
}

\begin{abstract}
RESUMO: $O$ artigo tem como objetivo estudar a representação da religião cristã nas narrativas ficcionais As Minas de Prata e Alfarrábios, de José de Alencar, a partir de figurações de práticas culturais que envolvem as tradições eruditas e populares do Brasil Colonial. Em ambas as obras, o registro da religião apreende as manifestações do povo e o imaginário coletivo em torno do mito cristão, perpetrados pelas práticas dos jesuítas e de sua catequese, pelas tradições dos santos e pelo imaginário cristão sobre os motivos da maldição. Entre sagrado e profano, entre santos e demônios, José de Alencar constrói uma quimera religiosa em suas obras, rompendo com a pretensa visão homogênea de religião cristã cultuada no Império.
\end{abstract}

PALAVRAS-CHAVE: religião cristã; romance histórico; crônicas; cultura popular e erudita.

ABSTRACT: This study analizes the representation of the Christian religion in the fictional narratives As Minas de Prata [The Silver Mines] and Alfarrábios, by José de Alencar, from the figurations of cultural practices, mainly considering the erudite and popular traditions of Colonial Brazil. In both works, the record of religion apprehends the manifestations of people and the collective imagination surrounding the Christian myth, perpetuated by the practices of the Jesuits and their catechesis, by the traditions of the saints and by the Christian imagination about the reasons of the curse. Amidst the sacred and the profane, amidst saints and demons, Alencar creates a religious chimera in his works, breaking with the so-called homogeneous vision of Christian religion worshiped during the Empire.

KEYWORDS: Christian religion; historical novel; chronicles; erudite and popular culture.

\section{Introdução}

Em 1857, José de Alencar publica nas páginas da imprensa o seu primeiro romance histórico, $O$ Guarani, cuja escrita e publicação integra-se a um projeto literário de constituição do passado nacional e do caráter identitário do país, fomentado pelo ideal de unificação política e religiosa. A religião cristã seria responsável pretensamente por unir o povo em torno de suas doutrinas eclesiásticas e por instruir e moralizar a

\footnotetext{
Doutora em Teoria e História Literária pela Universidade Estadual de Campinas (UNICAMP). A autora realizou recentemente Pós-doutorado em Estudos Literários pela Universidade Federal de Sergipe (PNPD/CAPES- Programa Nacional de Pós-Doutorado da CAPES), e, atualmente, é pós-doutoranda (PNPD/CAPES) do Programa de Pós-Graduação em Letras da Universidade Estadual Paulista, campus de São José do Rio Preto. E-mail: Rafaelamsanches@gmail.com
} 
nação. Religião, povo e território resguardariam, assim, os traços que legitimariam a formação do Brasil, delineando-se como temas a serem debatidos na imprensa e no Instituto Histórico e Geográfico Brasileiro (IHGB), lugares que orbitam em torno da política Imperial e difundem os assuntos de relevo ao processo identitário.

Debruçando-se sobre a memória do país, José de Alencar transita entre os diversos campos representativos da cultura brasileira, influindo sobre o registro da história à luz de uma perspectiva edificante, sobre a invenção de mitos nacionais e de elementos regionais que supostamente traduziriam o nacional. No conjunto de suas obras, as narrativas consideradas fundantes exploram a reinvenção do Brasil Colonial, cujo campo de representações é circunscrito às maneiras de narrar o passado. Dentre os assuntos que imperam nos discursos historiográficos, a religião católica, a miscigenação e as tradições do povo, vinculadas aos papéis que exerceriam no desenvolvimento do Brasil, recebem lugar de relevo em obras de Alencar, como em O Guarani (1857), Iracema (1865), As Minas de Prata (1865), e Alfarrábios: crônicas dos tempos coloniais (1872), textos que compartilham entre si a atenção voltada para o período de fundação do país e para o ideal de coletividade. Não por acaso, tais narrativas tematizam a gênese da pátria e conferem, de diferentes formas, atenção ao povo, à medida que registram com nuances o passado nacional. Com efeito, a produção da década de 1860 e, sobretudo, a de 1870 colocam gradativamente o manancial popular no centro da ficção e problematizam as origens do país, conforme fragilizam a linguagem altissonante dos primeiros escritos. Se em $O$ Guarani, a gênese do Brasil é pensada a partir da união do índio com o branco sob a perspectiva de um final mítico, em Iracema, por sua vez, a miscigenação, a despeito da dicção mítica, fratura o tom grandiloquente do primeiro romance. Em As Minas, publicado na mesma época de Iracema, a ficção explora com mais nuances as misturas de etnias junto às tradições da entidade coletiva, e de suas relações com religioso, o que já aparece timidamente em $O$ Guarani. Em Alfarrábios, o componente histórico que, de acordo com os postulados da época, atestariam a veracidade dos escritos de José de Alencar, é afrouxado, aproximando-se das narrativas lendárias, tão recorrentes ao seu momento de produção. A escolha por escrever uma obra que pudesse dar vazão à ficção dialoga diretamente com o assunto a ser tratado, a memória do povo, de suas tradições e de suas histórias, impregnadas em suas narrativas, por repertórios e crenças da religião e arraigadas nas práticas locais do período da colonização. Logo, a vertente religiosa e suas representações ambíguas são exploradas em Alencar, sendo que as figurações da religião e do popular ganham maior expressividade em As Minas e em Alfarrábios.

Ora, As Minas de Prata e Alfarrábios concedem um lugar privilegiado à cultura popular e à formação da esfera eclesiástica no país. O romance histórico As Minas explora os boatos em torno das minas de prata, o El dorado brasileiro, além das festas e cortejos populares ao redor da religião católica, enquanto Alfarrábios aprofunda a dicção popular, ao colocar em cena, não a matéria atestada pela veracidade, de acordo com os postulados da época, mas sim a matéria permeável à imaginação, contemplando as lendas que constituem imagens do Brasil Colonial.

Em As Minas, a trama enfoca as lutas e aventuras pela posse do roteiro das minas de prata no século XVII, feito pelo personagem Robério Dias, o que desperta os rumores sobre o misterioso local. As fabulações em torno das pedras preciosas alimentam o imaginário popular entre terras portuguesas e espanholas, e as pedras tornam-se objeto de desejo e ambição por diferentes personagens, inclusive, pelos próprios membros da Companhia de Jesus. O enredo sobre as minas é extraído do 
historiador Rocha Pitta, conforme as notas do romance histórico atestam e dialogam contundentemente com as imagens do El dorado brasileiro fabricadas desde o início da colonização. A prosa de natureza histórica apropria-se do mito que forjou os motivos da terra prometida e foi passado de geração a geração por via da transmissão oral. Não fortuitamente, os eclesiásticos possuem função importante na difusão do $\mathrm{El}$ dorado, visto que eram responsáveis pelo registro das riquezas da colônia a ser enviado à Metrópole, e cujas formas de levantamento se davam mediantes manobras políticas sobre o seu público. Ainda que direcione críticas ácidas às práticas eruditas dos membros da Igreja Católica, Alencar elege o cristianismo como religião protagonista para suas obras, de maneira que os povos que professam outras religiões, como os judeus, são registrado sob o horizonte de tipificações negativas que os corou ao longo do mito cristão.

Alfarrábios, por sua vez, explicitamente vinculada pelo subtítulo ao gênero cronístico, apresenta como proposta inicial recolher relatos de episódios históricos dos seiscentos, apreendidos nos momentos de fundação da cidade de São Sebastião e de Olinda. Divididos em três crônicas, os relatos tecem reflexões sobre a participação popular e a transmissão da cultura oral no período de formação do território colonial, valorizando o tom lendário, à medida que os textos cronísticos, a princípio vinculados à historiografia oficial, afrouxam sua concepção de "verdade" (característica do gênero histórico) ao ponto de emancipar as fronteiras entre discurso oficial e o imaginário coletivo. A primeira crônica, "O Garatuja", apresenta um episódio da concorrência do poder atemporal com o temporal, apreendendo os conflitos e entraves que circundam a fundação da Igreja de São Sebastião junto ao povo; a segunda, "O Ermitão da Glória", narra as superstições dos marinheiros em torno de Nossa Senhora da Glória, padroeira dos "homens do mar", e da fundação de uma ermida em sua homenagem. A terceira, "A Alma do Lázaro", explora as experiências de um leproso durante a fundação de Olinda.

Nessas crônicas, Alencar emula um narrador oral que conta as lendas e histórias populares, plasmando-as em diferentes modalidades literárias. Na primeira narrativa, a crônica se aproxima da sátira, ridicularizando a figura dos jesuítas, na segunda, se aproxima de uma espécie de narrativa hagiográfica, ao contar a história do ermitão da Glória, e na terceira, aproxima-se de uma espécie de discurso memorialístico, ao apresenta as memórias de um escritor moribundo, Lázaro, cuja deformidade pela lepra o leva a ter uma vida errante, e assim, se aproximar do imaginário do maldito e amaldiçoado que tanto alimenta as lendas do Judeu Errante.

A ficção Alfarrábios, diferentemente dos escritos anteriormente citados aqui, concede maior ambiguidade à construção do passado nacional, explorando, para além da temática da miscigenação entre povos, o material lendário. Assim, a cultura popular é entrevista como um espaço de diálogos com a cultura erudita, ora como espaço convergente, ora como refratária, mas sempre como privilegiada para retratar os costumes e a época, cuja autenticidade na obra é atestada pela representação do espírito coletivo. Os motivos religiosos se inscrevem, em Alfarrábios, como elementos de crise e ruína, por um lado, e de encantamentos do cotidiano, por outro, e seus aspectos integram o repertório do popular e do erudito. Em sua extensa figuração na narrativa, a religião é difundida pelos membros da Companhia de Jesus, recebendo críticas e sátiras no exercício de sua institucionalização em "O Garatuja"; é integrada ao culto e ao maravilhoso popular, plasmando um material lendário redimensionado pela narrativa da vida do ermitão da Glória e ressignificado em face ao espírito considerado amaldiçoado de Lázaro. 
Sendo assim, este artigo propõe-se a estabelecer um cotejo entre as representações da religião cristã de As Minas de Prata e as de Alfarrábios, sob as figurações do mito cristão, das doutrinas do cristianismo e de sua institucionalização no Brasil, que constroem as práticas populares e as eruditas. Atentaremo-nos para as formas com que a esfera religiosa traduz os costumes da "gente comum" e da aristocracia, difundidos em práticas que ora se apropriam de imagens em torno de santos e demônios para explicar os fenômenos e acontecimentos do mundo, ora corrompem a figura de religiosos missionários, sendo, por isso, a forma institucionalizada do catolicismo criticada por diferentes vozes.

\section{Configurações dos jesuítas em As Minas de Prata e Alfarrábios: da crítica séria ao riso zombeteiro}

O pensamento de José de Alencar sobre estar a serviço da sua pátria e dos ideais espirituais e civilizatórios, legitimados pela imagem da catequese e das doutrinas moralistas e dogmáticas da Igreja Católica, esboçam o seu olhar na reconstituição do passado brasílico e, de certa maneira, na sua projeção do Brasil Imperial. Se os processos de nacionalização da Instituição Religiosa configuram diversificados conflitos na percepção de um passado coerente e unificado, Alencar reabsorve as contradições da esfera eclesiástica, encaminhando determinadas representações, cuja ambiguidade se realiza no aproveitamento do catolicismo em outras áreas e esferas.

Em As Minas de Prata (1865) e Alfarrábios (1872), a representação religiosa e as querelas políticas da Monarquia Católica de Portugal são circunscritas como um problema histórico e identitário, que traçam um elo em comum entre as obras do escritor. Aliás, os movimentos polêmicos da Igreja Católica, e, sobretudo, da Companhia de Jesus no território brasileiro estabelecem pontes temáticas entre os referidos textos.

As representações dos jesuítas à luz de suas práticas pouco escrupulosas levantam suspeitas por parte das vozes de personagens e do coletivo, sendo que, em ambos os escritos, a ficção alencariana responde aos entraves contemporâneos com maneiras distintas. No romance histórico, a escolha de uma dicção séria, consoante à postura redentora por parte da Corporação Religiosa, entra em diálogo com a proposta do gênero de representar a ficção com nota de veracidade e, supostamente, com menor liberdade imaginativa ("controle do imaginário"), e, com efeito, de instruir seu leitor. Já, em Alfarrábios, a forte inclinação à escrita satírica no texto "O Garatuja", cujo gênero crônica flexibiliza as instâncias entre ficção e história e explora o elemento da tradição popular, forneceria combustível necessário para os efeitos fabulatórios e para as manifestações cômicas do povo. Assim, a tentativa do autor em parodiar a cultura erudita, coloca o povo como protagonista da história. Com efeito, em As Minas, o herói da trama, descendente do personagem histórico Caramuru, desmascara a conspiração dos jesuítas, ao passo que, em Alfarrábios, o personagem do povo, o enjeitado Garatuja, lidera um motim contra os prelados, promovendo uma rebelião popular contrária aos clericais da época. Enquanto o personagem protagonista aristocrático da prosa ficcional histórica consegue revelar o catecismo secreto dos padres, em "O Garatuja", o integrante do povo satiriza o relaxamento moral da Companhia.

Alfarrábios, ainda que escrito posteriormente a As Minas, retoma as figuras dos padres e as imagens negativas dos jesuítas do romance histórico, que ultrapassam seus 
ideais espirituais, e estabelecem uma relação questionável e complicada com a representação do povo. As Minas de Prata explora embates religiosos que são repensados em outros romances e narrativas, pois, apesar de separados por anos, eles apresentam um consenso na apreensão dos movimentos jesuíticos. Podemos interpretar que Alencar propõe uma conexão entre as recriações dos membros clericais, pois elas, em diferentes dosagens, estão envolvidas com a formação espiritual, educacional e política do Brasil, levantando indagações quanto ao desempenho jesuítico na moral e na ética.

No romance histórico, o personagem Gusmão de Molina é descrito como um jesuíta conspirador, cuja única devoção seria a representantes eclesiásticos poderosos e reconhecidos, pouco afeitos ao culto espiritual e aos rituais religiosos. A atuação de Molina reveste-se de mistério e de manobras planejadas às escuras, revelando aos poucos uma catequese secreta e intuitos de enriquecimentos ilícito da Ordem Religiosa, que, por meio de uma extensa rede de contato em diversos lugares e países, age como manipuladora da população local, extraindo do confessionário informações precisas para levantar fundos, e manejando estratégias para obter pontos de apoios junto a governadores. Por sua vez, o inaciano busca encontrar as tão famosas minas de prata na colônia portuguesa, e entraria na disputa pelas pedras preciosas, aproveitando-se dos personagens conforme lhe fossem convenientes, induzindo a um relaxamento moral que levaria, inclusive, personagens à morte. Não por acaso, a prática do catolicismo é encarada como problema na consolidação da pátria.

Dentre as maneiras de escrever a história da Companhia, a narrativa representa na sua estrutura romanesca o movimento de criação dessa Ordem, movimento esse que resgata o discurso controverso, exaltado e opositor que demarcou divergências no próprio seio da esfera eclesiástica. José de Alencar articula as dissidências entre os jesuítas Molina e Louriçal, tendo em vista que elas já aparecem na Companhia desde o seu surgimento, e são reformuladas no decorrer de séculos, o que faz com que o literato, ao lado dos seus contemporâneos, articule a dimensão histórica das imagens jesuíticas com o contexto local.

Em As Minas, a Companhia é responsável pelo ensino da população local; a ela, é reservada a cultura letrada, à medida que a narrativa descreve e relata os longos anos de estudos dos clericais para obterem a formação eclesiástica. As zonas de contato entre a cultura letrada e a popular seriam representadas principalmente pelo espaço da Sé, e pelos confessionários, momentos em que os padres colhiam informações para o registro escrito dos costumes locais em seus alfarrábios, extraído de uma fonte popular, por sua vez, considerada menos segura. Os escritos sobre as minas, por meio de vozes nos confessionários, foram levantados por Molina, por exemplo. Desse movimento de circularidade, a lenda das minas constrói-se em torno da oralidade, transformando-se num conto popular, que nutria a imaginação das pessoas. A Instituição Religiosa adotando um papel de protagonista frente à busca do El Dorado tiraria proveito do filho do descobridor das minas, Estácio, mantendo-o sob vigilância contínua. Estácio, por sua origem mestiça, experimentaria uma trajetória de representante da nação, e desmoralizaria o padre Molina. O final da história conta com tragédias e com mortes, o que dá uma dicção menos altissonante à narrativa.

Entre o mestiço nobre e o religioso corrupto, a prosa constrói os problemas identitários da nação, refletindo também sobre a dificuldade do registro histórico daquela época, cujos documentos seriam fornecidos pelo material dos jesuítas e pelas versões orais das minas. A perspectiva fragmentária do romance referenda, ainda que 
timidamente, ao caráter insuficiente da voz narrativa em retratar o passado da nação. Nesse sentido, José de Alencar promove uma discussão sobre a própria confecção de seu romance e de sua veracidade histórica, ao mesmo tempo em que considera o espaço do povo na escrita da história. Em outras palavras, o autor traz para a sua produção romanesca a presença de alfarrábios, a figura de padres cronistas e referências a documentos de época, que articulam, de forma fragmentada, as fontes históricas, bem como a própria construção da obra. Ao mesmo tempo em que os padres trocam cartas e escrevem alfarrábios, o romance se escreve nas mais variadas formas, trazendo as possíveis versões das minas. Ao se tomar que os jesuítas faziam "histórias", o romance histórico, a crônica e os alfarrábios, se embasam na relação entre diferentes narrativas e diferentes níveis de veracidade, de modo que estas relações parecem tensionar timidamente os componentes entre imaginação e história; entre campo popular e campo histórico. Na obra, os registros seriam escritos por conta do que se ouvia no confessionário, de modo que este espaço se perfaz como o mediador entre duas culturas distintas, convocando o povo para o papel de difusor da memória da pátria.

A leitura antijesuítica que sua obra realiza diante das controvérsias clericais do seu momento de produção, circunscreve uma crítica séria ao papel dos jesuítas, e atende às preocupações de seus contemporâneos. Sobretudo, em meados do século XIX, os loiolanos ocupam a atenção dos letrados por ameaçarem a autonomia administrativa do Império. Por sua vez, a inclinação antijesuítica de José de Alencar receberia uma nova dicção em Alfarrábios, o tom satírico. O poder eclesiástico é satirizado por meio de manifestações de imagens grotescas referentes ao baixo, cujo tom visa à libertação dos dogmas pouco moralistas dos clérigos. Nesta narrativa, a participação do povo que, em As Minas, fica relegada, sobretudo, ao contato com os inacianos, aumenta proporcionalmente à exploração de relatos de lendas e tradições que ressumbram os costumes populares, e ganham autonomia para ridicularizar os membros clericais.

Na primeira crônica de Alfarrábios, "O Garatuja", a cultura popular é apreendida pelas crenças e valores evocados pelo evento de uma construção da igreja; pelas superstições em torno do personagem Garatuja, oriundas do simples fato de seu nascimento ter se dado sob circunstâncias misteriosas; pelo culto popular, representado pelas novenas; e sobretudo, pelas manifestações artísticas e movimentações da turba, as quais exploram o riso e o rebaixamento, fornecendo referências para que a obra explore os pontos de interação e os espaços de mediação entre o erudito e o folclórico. As caricaturas do personagem Ivo, conhecido como Garatuja, exploram o material de arte e colocam em debate o lugar do artista. As atuações desse sujeito lançam reflexões em torno do espaço do artista junto ao povo, pois, a princípio, à sua revelia, o protagonista participa de um movimento de resistência à emancipação do poder tirânico da religião, sendo, pois, um símbolo de irreverência.

Ivo transita entre a cultura escolástica e a do povo, e se por um lado, representa o mediador entre elas, por outro se localiza como elemento de rebeldia dentro do sistema de crenças. Garatuja parodia a cultura de cima, fazendo desenhos dos religiosos, e inferindo no sistema de práticas da religião como único e hegemônico. Num segundo momento da crônica, Ivo, vulgo Garatuja, faz uma pintura visando intervenção política, pois, já consciente do seu lugar, lidera o motim contra o prelado.

Com acesso aos conhecimentos eruditos da Companhia de Jesus, o referido personagem a renega, e, ao contrário de apresentar uma vocação religiosa, faz retratos satíricos dos jesuítas, enveredando-se pela arte pictórica e pelo riso. Considerado um burlador impenitente, é expulso da Companhia. A vocação do protagonista dá nome à 
crônica; não por acaso, é significativa no desenrolar da história, ao incomodar as autoridades, visto que sua arte acompanha os movimentos dos poderosos da Igreja e suscita reflexões, instigando o povo contra as autoridades.

Um dos desenhos de Garatuja que causou rebuliço entre os jesuítas foi um quadro que tematiza a submissão dos religiosos aos caprichos de viúvas ricas. Garatuja retratou um carneiro a correr com uma velha sobre suas costas, e atrás do animal, desenhou vultos com roupas pretas, cujos narizes farejavam o objeto que estava adiante. A pintura fazia, assim, uma caricatura sobre um acontecimento da época, visto que os jesuítas atendiam as veleidades de uma viúva rica a fim de herdar sua herança; contudo, tal mulher não lhes deixara quase nada em seu testamento. O feito de Garatuja foi compreendido como desacato e blasfêmia às figuras de respeito da colônia, haja vista que os efeitos cômicos do quadro rebaixaram os religiosos, que retratados sob o símbolo de narizes que cheiram o baixo corporal de um animal, foram expostos ao ridículo, metaforizando a situação do desengano dos jesuítas. Ao lado dessas imagens simbólicas dos clericais, outro desenho com grande significância dentro da obra, foi realizado quando Garatuja já liderava a turba contra os religiosos, e realizou uma pintura misturando corpos de animais aos rostos dos membros dos eclesiásticos, o que gerou um riso incontrolável por parte da multidão.

As possibilidades subversivas da imitação não passavam despercebidas, pois as próprias formas dos elementos eruditos eram ridicularizadas pela imitação, e o mundo oficial era "virado de ponta-cabeça". Assim, revelando o mundo às avessas, motivo reincidente nas formulações de Bakhtin (1993) sobre realismo grotesco e carnavalização, Ivo desperta o povo para sua função e papel social, no caso, relacionados à memória da cidade, e à política. $\mathrm{O}$ riso entra como mecanismo de diferenciação; destruindo a seriedade do grupo clerical, influi sobre a base do grotesco, e corrói o discurso sério e unilateral.

$\mathrm{Na}$ obra, as vias do grotesco se manifestam como formas inerentes à dinâmica do ciclo da vida do povo, para elaborar uma forma de riso baixo e redentora, que dessacraliza os aspectos sublimes da Ordem dos Jesuítas por meio de uma desmitificação de sua imagem, surtindo o riso fácil e reduzindo a vida oficial ao universo caricaturesco, sob a perspectiva da bufonaria. A sátira ao modo de vida dos jesuítas, pautando-se nas imagens ligadas ao baixo corporal, remeteria à dinâmica das práticas religiosas, reduzindo-as ao espantalho cômico. As cenas das pinturas grotescas parecem desafiar a lógica conforme o tom de blasfêmia desafia os representantes de Deus. As manifestações populares que parodiam o mundo oficial são próprias das dinâmicas dos coletivos e de suas práticas festivas que transitam pelas praticas eruditas e a as apropriam por meio de seu repertório.

Do tom sério ao riso baixo, as obras de Alencar promovem respostas negativas à presença dos jesuítas no Brasil, dado o seu contexto particular. Nos oitocentos, a Ordem entraria em circulação nos mais diversos países, e chamaria a atenção tanto por seus avanços políticos quanto pelos avanços econômicos, sendo que, no Brasil, é reinventada como símbolo dos missionários, ou como figura decadente e corrupta do mito jesuíta de Pombal. Em diálogos com seus conterrâneos, e por meio de modalidades literárias específicas, o romancista representa a Companhia numa mesma época, o século XVII. A nota de seriedade do romance histórico As Minas cede espaço para a sátira e convocação do povo em Alfarrábios; logo, a dinâmica da caricatura apresenta-se dentro dos festejo tão afeitos as comemorações populares. Ao conceder espaço à 
protagonização do coletivo, a sátira e o riso baixo são incorporados na estrutura como reminiscências dos costumes da cultura popular.

\section{O missionário e o ermitão: a trajetória lendária de dois santos}

Se em meados do século XIX, as leituras antijesuíticas acalentam as páginas da imprensa, por outro, o debate em torno dos loiolanos também deixa entrever uma imagem positiva dos religiosos. Sob uma vertente dúbia, a Companhia de Jesus terá uma imagem elevada em decorrência dos primeiros jesuítas do Brasil, "os missionários", e outra decadente atribuída aos jesuítas corruptos, posteriores à fase áurea da Companhia. Com menor atenção e alcance, a figura do missionário também aparece em Alencar. Entre os letrados, sobretudo, os do Instituto Histórico e Geográfico Brasileiro, a escrita e a reinvenção da pátria compreende a memória dos jesuítas missionários e perpassa por uma linguagem sublime, altissonante, descrevendo a vida de sacrifícios dos primeiros religiosos. Essa linguagem é plasmada em As Minas de Prata em torno do reverendo Ignácio de Louriçal. A imagem de eclesiásticos aproximada da de santos e anjos já entra em circulação em outras obras ficcionais da mesma época, e se configuram como importantes referências para As Minas, como o personagem Gabriel de $O$ judeu errante, de Eugène Sue. Assim, os elementos sublimes atribuídos aos jesuítas são confeccionados pelo mito do missionário, e pelas histórias lendárias sobre os grandes feitos extraordinários e heroicos dos primeiros padres do Brasil Colônia, narrados nas crônicas jesuíticas e que serviriam de modelo à prosa alencariana.

Em As Minas de prata, o padre Ignácio de Louriçal representa a entrega do jesuíta à missão espiritual e, por extensão, à catequização dos índios. Em contraste com Molina, Louriçal questiona de maneira contundente os ideais de seu colega travando grandes discussões com outros membros. Contrapondo-se à corrupção da Ordem, retirase para o sertão, demonstrando uma trajetória de sacrifícios e austeridade.

Os princípios de Louriçal são reapropriados na figura virtuosa de Ayres de Lucena no texto "O Ermitão da Glória - lenda", de Alfarrábios. Ao gosto da sensibilidade romântica, as virtudes redimensionadas pelo forte apelo lírico que apreende poeticamente a vida reclusa e de grande devoção a santos de Ayres, são marcadas por melancolia e mistério. Louriçal aproxima-se de Cristo, Ayres torna-se uma imagem cultuada por sua devoção à Santa dos Marinheiros, e ambos vivenciam situações sob os expedientes de tragédias, de sofrimentos, tornando-se referências para o coletivo e, sobretudo, no caso de ermitão, para o imaginário da época.

Em As Minas, as representações da Ordem Inaciana oscilam entre dois polos contrastantes; em uma delas, o romance representa a missão catequizadora dos jesuítas e suas dificuldades perante as diversidades das matas embrenhadas, bem como a resistência dos aborígenes:

O mancebo [Estácio] reconheceu imediatamente, no venerável apóstolo do deserto, seu antigo mestre do Colégio da Bahia, o padre Inácio do Louriçal. O santo homem, voltado ao martírio, conservava a mesma placidez e mansa humildade, que ornavam seu semblante, oficiando no altar, ou lendo nas aulas. A alma posta em Deus, que ele via no arroubo de sua fé, não se apercebia do que se passava na terra, nem sentia as torturas que o pungiam; seu espírito abreviara as tribulações da vida, e já despregava-se de 
uma carne seca e definhada para voar ao seio do Criador. (ALENCAR, 1958a, p. 1139 e 1140; grifo nosso).

Neste contexto, o jesuíta Ignácio se encontrava em pleno ritual antropofágico, e, após ser salvo pelo protagonista, continua sua missão no sertão:

\begin{abstract}
- Esta é minha missão, Estácio, enquanto não chegar a minha hora. Até lá Deus virá em meu auxílio, como hoje, como tantas outras vezes. Aqui serviu-se ele dos vossos braços valentes, meus filhos; lá da voz débil de seu servo; amanhã ninguém sabe de quê. Tudo serve aos poderosos desígnios da Providência.

$[\ldots]$

Estácio desde a separação do Padre Inácio, que ficara pensativo; aquela nobre abnegação e sublime caridade deviam de impressionar uma alma feita como a sua para os grandes e generosos impulsos. Ele envergonhou-se de seu valor e intrepidez comparando-os àquele sereno heroísmo do mártir, que em outro estímulo mais que a fé robusta, se afrontava com o suplício horrível e bárbaro, e buscava a morte obscura e ignorada com o mesmo entuasiasmo do soldado que marcha à conquista da glória no campo de batalha. (ALENCAR, 1958a, p. 1145 e 1146; grifo nosso).
\end{abstract}

Nas passagens que simbolizam o sacrifício do padre Inácio em nome da Ordem a estrutura textual articula os aspectos estéticos e temáticos das crônicas da Companhia de Jesus, como a visão providencialista e os ingredientes do discurso épico, que se reestruturam no discurso literário sobre a atuação espiritual do missionário. Assim, a presença de Inácio no sertão consagra e sacraliza a imagem dos jesuítas como peregrinos, dispostos a arriscar sua vida pela pregação, elementos veiculados pelos tratados referentes à Companhia, como o livro do Padre Simão de Vasconcelos, o de Fernão Cardim, e dentre aqueles que aparecem citados na própria obra de Vasconcelos. Ao lado dos escritos da própria Companhia, a imprensa e o IHGB representam os primeiros anos dos jesuítas na América como o "período áureo". $1 \mathrm{Na}$ obra, as representações das missões e do caráter educador também se fazem presentes.

\footnotetext{
${ }^{1} \mathrm{Na}$ trama alencariana, as fortes imagens exploradas do jesuíta sacrificado no sertão faz jus à figura do missionário, contemplando os inacianos mártires do Brasil. Dos jesuítas da primeira geração, damos relevo ao jesuíta Anchieta que ganha espaço por conta de sua Beatificação em Roma ( $A$ ABELHA RELIGIOSA, 01/08/1854, p. 4). Assim, os tempos áureos dos inacianos são simbolizados na imagem do padre Inácio. A mitificação dos jesuítas da primeira geração construída pelo IHGB ganha força ao ser legitimada em Roma, servindo de fonte histórica a obra de Alencar: "Cartas de Roma anunciam que para dezembro ou janeiro seguintes, estará já terminada a causa dos quarentas jesuítas, que tendo por chefe o padre Inácio de Azevedo, e dirigindo-se ao Brasil, foram martirizados junto à ilha das Palmas, pelo furioso calvinista Jacques Soria, em 15 de julho de 1570. Desde muito que tem culto público em Roma, e parece que o processo tem por final principal provar a legitimidade desse culto." (DIÁRIO DO RIO DE JANEIRO, 22/12/1853). O culto apresentado pelos jesuítas redimensiona as imagens de tortura dos loiolanos no Brasil, enquadrando-os dentro do discurso que reconstroem os inacianos como missionários, dispostos a morrer por sua missão. Nesse sentido, eles são representados como poderosos modelos de integrantes a serem seguidos, de forma que aponta uma linha de continuidade, pois a atuação deveria ser seguida. Ou seja, os jesuítas em Roma, ao mesmo tempo em que circunscrevem a memória do seu passado, a projeta para o presente, fazendo se legitimar no culto, representante das linhas tênues entre passado-presente. Da mesma forma, José de Alencar, ao construir os sacrifícios do personagem Inácio, consegue reviver o passado simbólico da Ordem, estendendo para sua obra os sentidos contemporâneos a ela, com os quais os seus leitores poderiam ter acesso. A rede de significação aumenta, ao levar-se em conta o romance de Eugène Sue, o Judeu Errante, que representa o jesuíta Gabriel sendo sacrificado.
} 
A figura mítica do missionário de As Minas auratiza a prática dos membros religiosos e a cultura erudita da época, confere dignidade à história do Brasil e ressumbra em outras obras do autor, como em Alfarrábios. Confeccionando a lenda do ermitão no paradigma da figura reclusa e que beira à santificação, a crônica redimensiona o tom épico do romance histórico, revestindo-o do maravilhoso popular em Alfarrábios, afeito as histórias de tragédias e às notas de encantamento exploradas do cotidiano do povo.

"O Ermitão da Glória" relata a história do marinheiro Ayres de Lucena e de sua trajetória junto à construção da ermida de Nossa Senhora da Glória, espaço dedicado à "Padroeira dos Marinheiros". Após não cumprir a promessa feita à Santa, o personagem perde sua mulher amada, e torna-se um eremita em estado profundo de meditação. $\mathrm{O}$ recolhimento, índice de sua redenção e devoção, torna sua experiência misteriosa, e atrai outros peregrinos ao local, transformando sua figura em material lendário. A história circunscreve uma experiência que transborda melancolia, dor, sofrimento, e que referenda à vida sagrada, contida na imagem da ermida, e à experiência individual do personagem, experiência autêntica que se aproxima do coletivo.

$\mathrm{O}$ culto à ermida transforma Ayres em um santo por dedicar sua vida a uma espécie de monastério. O lugar transforma-se em um antro sagrado. Do âmbito de sua experiência individual, a história de Ayres transita para a construção do imaginário coletivo na obra, e alimenta a primeira memória da ermida do Rio de Janeiro. A narrativa aproxima-se da atmosfera do medievo, conforme recupera a imagem das hagiografias e das histórias de santos que sacrificam suas vidas, sendo aqui a história de Ayres muito mais reconhecida pela difusão oral do local do que propriamente pelos aspectos de santidade do personagem.

Com efeito, a ermida se transforma em lenda, ao passar de um personagem para outro, de Ayres para Caminha, de uma narrativa a outra, via transmissão oral - e os mediadores dessa dinâmica são os peregrinos:

\footnotetext{
Antônio de Caminha aceitou o legado de Ayres de Lucena. Vestiu a esclavina do finado ermitão, e tomou conta da gruta onde aquele vivera tantos anos.

Viera [Antônio Caminha] àquele sítio como em santa romaria para obter perdão do agravo que fizera á imagem de Nossa Senhora da Glória, e chegara justamente quando expirava o ermitão que a servia. Resolveu, pois, consagrar o resto de sua vida a expiar nessa devoção a sua culpa. Toda a gente de $\mathrm{S}$. Sebastião e muita de fora iam em romagem ao outeiro levar as suas promessas e esmolas [...] (ALENCAR, 1958b, p. 115).
}

Por sua vez, o ermitão da Glória demonstra uma consciência elevada diante dos fenômenos corruptíveis do mundo, pois, para alcançar o caráter da "grandeza", própria do eremita, priva-se de experiências empíricas e, através de um esforço contínuo, anula seus desejos e paixões. Nesse ponto, a linguagem assume seu caráter sublime. Ao viver em condição de silêncio absoluto e de isolamento, ele experimenta não só um estado de privação, a partir do qual tenta encontrar sua redenção, mas também constrói um local sagrado para a comunidade. Daí se entrecruza sua tragédia pessoal com a fundação de um lugar sagrado. Sua devoção acaba sendo reconhecida, e o título ermitão da glória dialoga com função religiosa ocupada pelo eremita.

Assim, as obras compartilham imagens em comum em torno do sujeito religioso que se sacrifica para servir à comunidade, incorporando os componentes da santificação, e compartilhando com as imagens dos jesuítas missionários as figurações míticas, cujos motivos como sofrimento, devoção, austeridade, são transferidos para os 
personagens. As imagens do sublime reverberam em ambas as narrativas, e contrastam com tipificações negativas dos jesuítas. A mentalidade reconstituída para época traduz, sobretudo, o olhar de encantamento da "gente comum" sobre as manifestações do maravilhoso do mito cristão naquela realidade local; em As Minas, com menor relevo, em Alfarrábios, com lugar de destaque.

Dessa maneira, as narrativas operam com as figurações do religioso em instâncias distintas, tecendo considerações relevantes sobre o espaço reservado à formação das tradições religiosas no Brasil.

\section{Malditos, errantes e hereges: as figuras amaldiçoadas do judeu e de Lázaro na ficção de Alencar}

A escolha de José de Alencar por ficcionalizar as doutrinas cristãs e sua difusão no território colonial por meio do registro da atuação dos missionários e dos membros do Colégio dos Jesuítas confere a sua escrita uma função moral e instrutiva cujas orientações exploradas são de naturezas espirituais, moralizantes e civilizatórias. O contato entre o prelado e o povo também confere lugar de relevo aos aspectos do repertório religioso popular. Ao eleger o cristianismo como referência mítica de suas narrativas, Alencar aproveita-se também dos motivos que cercearam negativamente figuras simbólicas e paradigmáticas do mito cristão, como o judeu e o personagem de Lázaro, sendo que os traços de ambos os personagens em suas obras instigaram a curiosidade e o mistério envolto da atmosfera do sujeito amaldiçoado e maldito, conforme o autor os aproxima do repertório de figurações demoníacas que receberam lugar de relevo no romantismo, por promoverem o estranho e inusitado, tão cultuado pela estética romântica. Daí ser possível depreender dos textos alencarianos motivos reincidentes que marcam determinados personagens e sugerem ligação entre ideias com forte apelo ao imaginário do subterrâneo cristão. Configurados por imagens da maldição e de seus desdobramentos para a situação de peregrinação e isolamento, comuns ao mito do judeu errante e ao ser maldito centrado em Lázaro, os pontos de contato, em maior ou menor grau, são compartilhados das imagens do "anjo caído".

Em As Minas de Prata, as ações dos personagens hebreus ressumbram um conjunto de significações que edificaram o mito do judeu errante, à medida que suas características entram em conflito com os personagens católicos. No romance histórico, os hebreus são os personagens que conspiram contra a pátria, pois, por não pertencerem ao território, visto serem imigrantes, formam alianças com os holandeses, a fim de tomá-la. A partir dos signos que parecem evocar o mito do errante, Alencar aclimata tais marcas simbólicas para a particularidade do território brasileiro. O judeu, em sua obra, incorpora os traços do peregrino e transita por diferentes espaços, entrando em contato com a aristocracia da época colonial e com a comunidade local, conforme necessita de comparsas. As tramas conspiratórias desse povo para invadir a Bahia são combatidas pelo personagem de origem nobre e popular, Estácio, ligado à memoria da pátria. Ora, Alencar opera em sua obra uma circularidade entre a cultura popular e a cultura erudita que se convergem e se tocam por via de seus olhares preconceituosos com relação ao judeu; também são tocantes conforme buscam tirar proveito da situação econômica deste grupo. As práticas dos jesuítas, por exemplo, perpassam pela aquisição de fundos levantados por meio da exploração financeira de uma viúva judia, e as práticas do povo 
percorrem as tabernas de Brás, tentando lucrar de diferentes formas com os planos do taberneiro.

Em Alfarrábios, o sujeito amaldiçoado ganha voz na própria narrativa, relatando os preconceitos de seu momento vivido. O período posterior à Guerra Holandesa, momento em que as anotações de Lázaro são encontradas, seria propício e oportuno para o registro de um personagem exilado em sua própria terra, devido aos preconceitos que o cercam. Sendo assim, a restituição da memória da Guerra Holandesa repercute nessas duas obras, em As Minas e Alfarrábios, ganhando dimensões sob as figuras malignas, pensadas como elementos expressivos e pertencentes à certa época, marcada por invasão, conflitos, e cenário conturbado.

Com efeito, em As Minas, os povos que não professam a religião cristã, como os judeus, por exemplo, são registrados de forma perniciosa, tendo em vista a consolidação de sua imagem como sujeitos traidores, conspiradores e usurários na literatura do ocidente. No Brasil, em particular, sua participação na invasão holandesa no século XVII contra os colonos portugueses contribuiu para radicação de um contingente imagético depreciativo. Ora, as representações antissemitas veiculadas pelo romance alencariano é produto de sua própria época, de uma atmosfera antijudaica que circula na imprensa e nos países de tradição católica, como a França, cujas produções folhetinescas de temáticas anti-israelita circulam com grande repercussão junto aos debates da imprensa brasileira. Por outro lado, os diálogos com seus conterrâneos sobre a presença nefasta dos judeus no período da Guerra Holandesa ajudou a difundir por meio da Revista do Instituto Histórico e Geográfico Brasileiro os estereótipos dos judeus como traidores da nação e sujeitos errantes. Alencar revisita, assim, essas tipificações desse grupo-étnico, sobretudo, os signos que ressonam o imaginário em torno dos israelenses como personagens errantes e peregrinos, justamente pelo fato de os judeus proferirem uma religião distinta da católica, e por serem estigmatizados no mito cristão; logo, são vistos como entraves e obstáculos à hegemonia da Igreja Católica no Brasil; por isso, são sempre representados sob o mal, amaldiçoados errantes, e rebeldes.

Em meados do século XIX, a preocupação sobre os hebreus que demarca as páginas alencarianas também toma as páginas dos jornais. Parte dos letrados que se lança na tarefa de pensar os israelitas perpassa pela preocupação religiosa, que se relaciona diretamente à manutenção da unidade nacional. Nesse sentido, a reescrita das guerras coloniais, aliás, as imagens do "Brasil Holandês" constroem representações da ameaça de outras religiões.

A efetivação da literatura antijudaica na imprensa fluminense de meados do século XIX é formada pela circulação de textos defensores da religião cristã no Brasil, que, juntamente com a circulação de publicações nacionais ou estrangeiras que revisitam e debatem os textos bíblicos ou fazem alusões a festividades Católicas, retomando os estigmas tradicionais do povo judeu, estimulam a contínua interpretação da imagem desse povo nos jornais e nos romances.

Não por acaso, a ideia de vagar e seu sentido simbólico acompanha a representação desse povo no jornal e no romance, juntamente com a ideia de amaldiçoado. O engajamento de Alencar nesta tradição se reflete na atmosfera conspiratória em torno dos hebreus em As Minas, que faz referência explícita à tradição dos judeus e à história do judeu errante, redimensionando os possíveis sentidos simbólicos deste mito, que tem como protagonista em várias de suas versões o judeu errante. 
Reinterpretada intensamente no século XIX, a figura do judeu Ahasverus ${ }^{2}$, que maltratou Cristo e foi castigado reacende a discussão em torno dos significados do seu mito, o judeu como um indivíduo sem "terra", o judeu como testemunha dos males, o judeu como um sujeito amaldiçoado. Sendo assim, a retomada e a reconstituição de suas adaptações e significados se tornam relevantes, ao considerarmos que Alencar estava em profundo diálogo com o que se consumia e se divulgava na imprensa fluminense a partir das conexões e trocas culturais entre Paris e Rio. No caso, estava em sintonia com a obra de Eugène Sue, $O$ judeu errante.

A figura de Ahasverus alimenta A Alma de Lázaro. Não por acaso, esta narrativa de Alfarrábios afrouxa as marcas de seu caráter histórico, promovendo uma prosa poética impregnada de características que chancelam a estrutura das narrativas lendárias sob o manto do mito cristão. As obras recuperam, assim, imagens e narrativas do mito cristão depositárias das simbologias do mal, como as de Lázaro e as do povo judeu, por exemplos, cujos traços negativos, sobretudo, o do maldito e do errante transferem-se aos aspectos grotescos atribuídos a um poeta de Alfarrábios, que, devido as suas formas físicas deformadas por conta da "doença de Lázaro" contaminar o imaginário da época abordada, sofre isolamento e censuras constantes. Sendo obrigado a viver em condição de migrante, o personagem poeta vive em situação similar a dos hebreus enquanto personagens considerados amaldiçoadas e imigrantes por excelência. As imagens de figuras malditas do mito cristão, como as dos judeus, alimentaram a cultura dos seiscentos, período abordado em Alfarrábios. Não por acaso, na obra, as imagens negativas dos hebreus são catalisadas nas do maldito atribuído a Lázaro.

O imaginário em torno do mito cristão alimentou a imagem do mal dos judeus, tão presente na imprensa, e reconhecível pela voz dos personagens de As minas. O romance histórico de Alencar convalidou as propagandas negativas desse grupo, contribuindo para a visão antissemita de seu momento. Não distante disto, o imaginário que circunda a personagem de Lázaro ganha voz na escrita do próprio personagem que deixa entrever o quão perturbador foi a história de Lázaro para a população local:

A notícia de minha enfermidade divulgou-se de um modo espantoso. Quando passava, apontavam-me de longe. Murmuravam meu nome. Realmente um Lázaro não é mais um homem. Foi concebido pela mulher, mas a praga o abortou. No terror que infunde é fera: no asco que excita é verme. (ALENCAR, 1958b, p. 168).

Alencar aproveitou-se da figura de relevo de Lázaro, e de sua presença perturbadora, como o próprio monstro, um "morto vivo", um "espantalho da morte", para adentrar em sua subjetividade e mantê-lo vivo na história local e na condição de poeta. O personagem, por suas características físicas sinistras, parece evocar um tom profanador para sua história. Não por acaso, o escritor entra em profundo diálogo com os interesses de seu período de produção. De um lado, os judeus ocupam a atenção dos letrados, por ameaçarem a hegemonia do cristianismo, e de outro, o escrito de Lázaro contempla a narrativa lendária e o repertório popular, configurando, por sua vez, como

\footnotetext{
${ }^{2}$ A figura lendária de $O$ Judeu Errante é representada na literatura e nas artes por meio de um velho muito magro, barbado, cabelo comprido e com o manto escuro. Segundo Cascudo (2002), a lenda narra a história da maldição de Ahasverus. O personagem exercia a função de sapateiro em Jerusalém e foi amaldiçoado por blasfemar contra Jesus Cristo. Isso ocorreu no momento em que Jesus passou com a cruz, momento da crucificação, e Ahasverus o empurrou, gritando para Jesus caminhar mais rápido. Após isso, foi condenado a vagar eternamente, sem descanso, e sozinho.
} 
uma espécie de conto metafórico para expressar a preocupação em torno da figura do poeta deslocado, experimentando as condições adversas de seu meio, também produto das reflexões dos oitocentos. Lázaro, por sua vez, aproxima-se da imagem de deslocado, e marginalizado, pois é sempre vitima da sociedade, enquanto os judeus são os malignos; por sua vez, ambos experimentam, a sensações de abandono, do desterro, e a situação de migrantes.

A peregrinação de Lázaro sob as preceptivas do imaginário cristão fomentou o mito de Lázaro e ajudou a difundir o sujeito errante, amaldiçoado pela "praga", conforme o relato do narrado e de sua voz que, no almejo de ser poeta, representou, pois, o deslocamento e o exílio de tantos escritores que viveram à margem da sociedade. Sob esse ponto, o mito de Lázaro aproxima-se do mito do poeta exilado, fundindo sua condição a de tantos outros, e, sobretudo, referendando os poetas do século XIX, que buscam na representação de experiências e no subjetivismo o elemento de autenticidade da voz poética oitocentista, em plena sintonia com os ideais de inspiração e do gênio romântico.

\section{Conclusão}

Em ambos os escritos de José de Alencar, As Minas de prata e Alfarrábios, as narrativas aproximam-se à medida que desenvolvem o contato entre a cultura erudita e popular em torno da religião cristã, tendo em vista a importância que o cristianismo obteve para o momento de construção identitária. Para os letrados, o culto à religião católica, manteria pretensamente o país unido, e sua reconstituição recuperaria os princípios morais.

As reflexões materializadas aqui estabelecem um vetor de força da esfera religiosa em As Minas e Alfarrábios sobre o mirante da cultura popular e cultura erudita, de suas zonas de interação e de práticas que as diferenciem, cujos posicionamentos e costumes ora indagam a postura dos eclesiásticos, ora constroem um manancial de encantamento, ora demonizam o "outro". Em particular, na segunda e terceira crônicas de Alfarrábios, o manancial coletivo penetra com expressividade na dicção das lendas; o ermitão transfigura-se num personagem excêntrico aos olhos do povo, enquanto Lázaro carregaria a própria praga, segundo a voz do coletivo. Um acolhido e o outro desprezado, o santo e o amaldiçoado espelham-se em posições diametricamente opostas, o que parece sugerir as formas de confinar os movimentos de ascensão e queda da religião num complexo imagético junto às práticas idealizadas no Brasil Colonial. Com efeito, as figurações da religião em Alencar transitam por diferentes repertórios, contemplando uma dicção crítica em referência ao exercício do clero e uma dicção lendária plasmada pelo registro do imaginário coletivo que se reflete sobre as figuras de santos e demônios e de seus desdobramentos para a constituição dos costumes dos povos comuns nas obras ficcionais alencarianas.

\section{REFERÊNCIAS}

A ABELHA RELIGIOSA. Rio de Janeiro, 1854. 
ALENCAR, José de. Alfarrábios: crônicas dos tempos coloniais. Rio de Janeiro: Garnier, 1872. . O Jesuíta. Rio de Janeiro: Garnier, 1875. 1893. Como e porque sou romancista. Rio de Janeiro: Tip. de G. Leuzinger \& Filhos, 418-1257.

As Minas de Prata. In: Obra completa. Rio de Janeiro: Aguilar, 1958a. p.

Alfarrábios: crônicas dos tempos coloniais. In Obra completa. Rio de Janeiro: Aguilar, 1958b. p.1268-1496.

Como e porque sou romancista. Campinas: Pontes, 2005.

BAKTHIN, Mikhail. A cultura popular na Idade Média e no Renascimento: o contexto de François Rabelais. São Paulo: Hucitec, 1993.

CASCUDO, Luís da Câmara. Dicionário do folclore brasileiro, São Paulo, SP: Global, 2002.

DIÁRIO DO RIO DE JANEIRO. Rio de Janeiro: Tipografia do Diário, 1853.

SUE, Eugène. O Judeu Errante. São Paulo: Brasil Editora, 1963. 